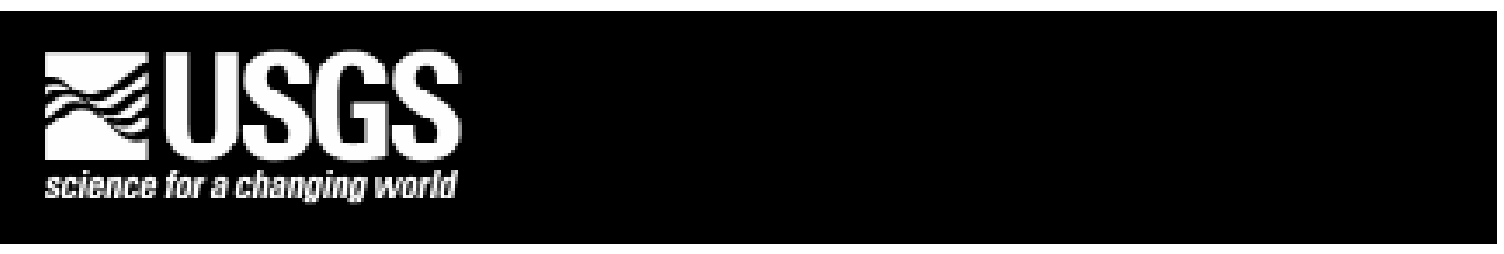

\title{
Digital Mining Claim Density Map for Federal Lands in Wyoming: 1996
}

\author{
by Paul C. Hyndman ${ }^{1}$ and Harry W. Campbell ${ }^{2}$
}

Open-File Report 99-542

Version 1.0

1999

This report is preliminary and has not been reviewed for conformity with U.S. Geological Survey editorial standards. Any use of trade, product, or firm names is for descriptive purposes only and does not imply endorsement by the U.S. Government.

This digital map, identified as "Digital Mining Claim Density Map for Federal Lands in Wyoming: 1996," has been approved for release and publication by the Director of the USGS. Although the digital map has been reviewed and is substantially complete, the USGS reserves the right to revise the data pursuant to further analysis and review. The databases are released on condition that neither the USGS nor the U.S. Government may be held liable for any damages resulting from their use.

Manuscript approved November 8, 1999

\section{U.S. DEPARTMENT OF THE INTERIOR \\ U.S. GEOLOGICAL SURVEY}

\footnotetext{
${ }^{1}$ U.S. Geological Survey, Spokane, WA 99201

${ }^{2}$ Retired, U.S. Geological Survey, Spokane, WA 99201
} 


\section{CONTENTS}

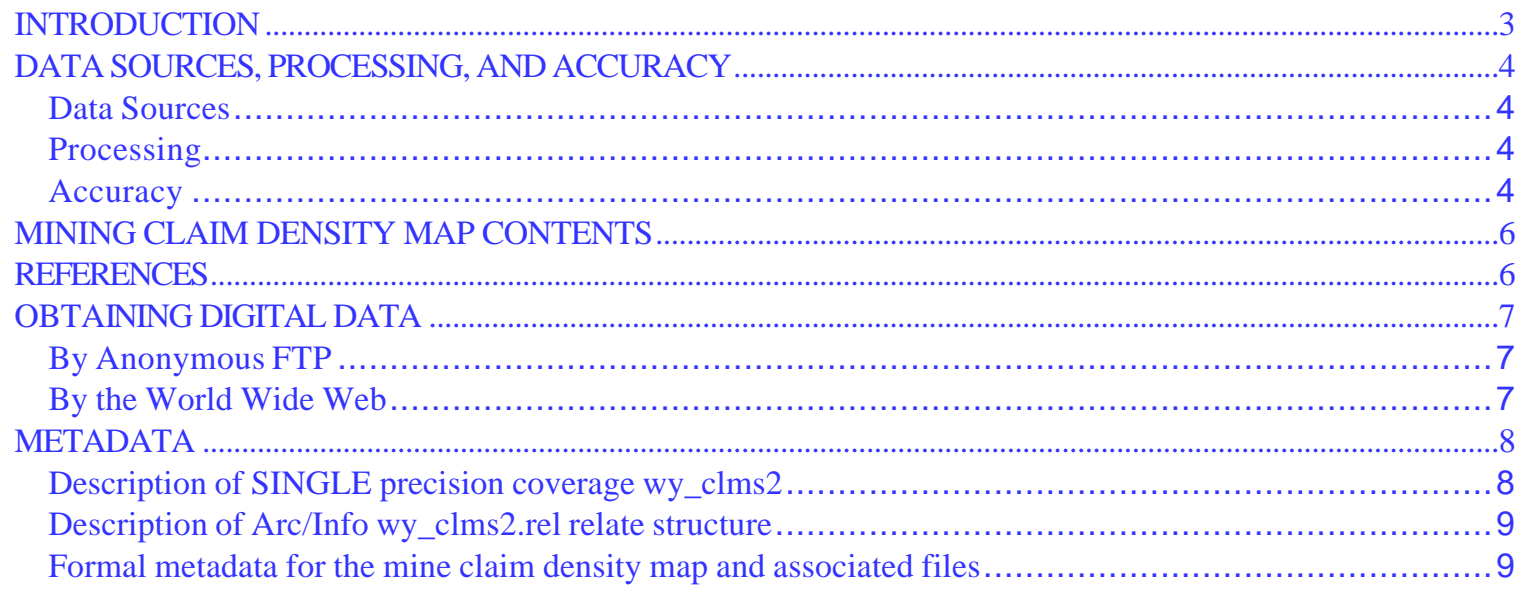

Figure 1. --- Open (black) and closed (gray) status of mining claims in Wyoming for 1996................................

Table 1. Mining claim totals by type and status in Wyoming (database linked to digital map).......................5

Table 2. Mining claim totals by type and status in Wyoming (wy_clms $2 . c l m s$ database)................................5

Table 3. Field structure and descriptions of specific fields for the digital map ...............................................6

Table 4. Field structure and descriptions for the mine claim density database................................................6

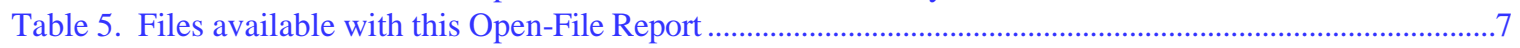




\section{INTRODUCTION}

This report describes a digital map generated by the U.S. Geological Survey (USGS) to provide digital spatial mining claim density information for federal lands in Wyoming as of March 1997. Mining claim data is earth science information deemed to be relevant to the assessment of historic, current, and future ecological, economic, and social systems. There is no paper map included in this Open-File report.

In accordance with the Federal Land Policy and Management Act of 1976 (FLPMA), all unpatented mining claims, mill, and tunnel sites must be recorded at the appropriate BLM State office. BLM maintains a cumulative computer listing of mining claims in the Mining Claim Recordation System (MCRS) database with locations given by meridian, township, range, and section. A mining claim is considered closed when the claim is relinquished or a formal BLM decision declaring the mining claim null and void has been issued and the appeal period has expired. All other mining claims filed with BLM are considered to be open and actively held. The digital map (figure 1.) with the mining claim density database available in this report are suitable for geographic information system (GIS)-based regional assessments at a scale of $1: 100,000$ or smaller.

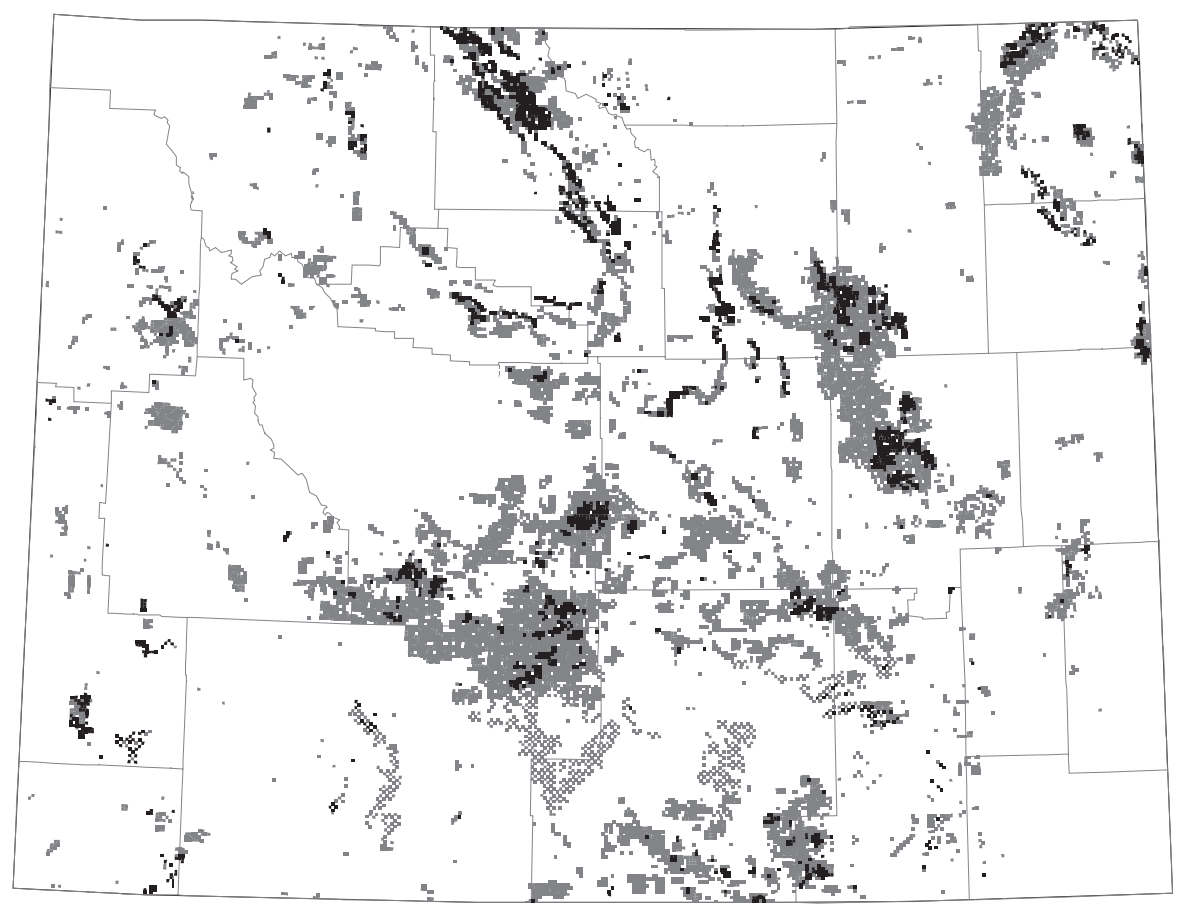

Figure 1. --- Open (black) and closed (gray) status of mining claims in Wyoming for 1996. 


\title{
DATA SOURCES, PROCESSING, AND ACCURACY
}

\section{Data Sources}

The mining claim density database of federal lands in Wyoming is one of 13 statewide databases published in the U.S. Geological Survey Open-File Report 99-325. The database contains information identifying 1) the meridian, township, range, and section (MTRS) designation, a unique record identifier, 2) the number and type of claims (lode, placer, mill site, tunnel site) within each section, and 3) the status of the claims (open is held by a claimant, closed is no longer held). The original mine claim data used to create the databases in OF99-325 were acquired from the BLM in March 1997. An official quarterly release of the MCRS mine claim data for Wyoming is available by specific request from the:

\author{
United States Department of the Interior \\ Bureau of Land Management \\ Mining Claim Recordation System Coordinator \\ NI-112, Denver Federal Center \\ P.O. Box 25047 \\ Denver, CO 80225-0047
}

The statewide Public Land Survey (PLS) digital map of Wyoming, wy_clms.e00, was used to create the digital mining claim density map. The digital map was in Arc/Info export format and was acquired as legacy data from the U.S. Bureau of Mines (USBM) that was closed by Congress in February 1996. No metadata information was available with this digital file. The PLS is assumed to be from 1:100,000 scale sources.

\section{Processing}

The digital file, wy_clms.e00, was imported using Arc/Info, version 7.1.1 (Environmental Systems Research Institute, Inc., Redlands, California), a commercially available GIS software, as an Arc/Info coverage into a workspace on a Sun Ultra 1 with Solaris 2.5.1 operating software. Each section of the new digital PLS contained a unique identifier corresponding in form to the MTRS in the mining claim density database. This digital map had been used for an older mining claim density database created by the USBM. The older data, which was directly attached to the coverage, was removed and the current database (blm_wy.dbf) from OF99-325 was linked, using a relate file, with the digital PLS of Wyoming. The linking process connected the data in the database to their corresponding sections in the digital map. The result was a digital mining claim density map (figure 1.) with the attributes of the current database. A subset of the digital map, that part containing mine claim density data, was created and named wy_clms2. This step was necessary because the PLS acquired from the USBM is not public domain data. However, subsets of the PLS, such as the one in this report, can be released provided that the PLS of the state cannot be recreated from the subset. The relate file was renamed wy_clms2.rel and the database of Wyoming from OF99-325 was renamed wy_clms2.clms. The renaming allows the database and the relate file to be included in the single export file, wy_clms2.e00, created when packaging the digital map for others.

Figure 1 displays the sections of the PLS containing claims and their status for this digital map. The map can be queried regarding its other attributes and can be used in investigating relationships with other digital data.

\section{Accuracy}

Several factors can affect the accuracy of the mining claim density database and digital map. The original data from BLM may contain errors. Two possible sources of error in the database are 1) incorrect position of the mining claim submitted by the claimant, and 2) input errors from the data entry papers to the computer database. 
The digital map of the PLS of Wyoming may contain errors. Possible errors include 1) misidentified sections, 2) sections with no identifying information, and 3) sections missing from the PLS digital map. These errors would result in incorrect locations of the mining claim density data or failure of the data to be connected with the digital map.

Tables 1 and 2, summarize the number of mining claims by type and status for the digital map and the database. The total number of claims in the digital map (table 1) do not agree with the total number of claims in the mining claim density database from OF99-325 (table 2). Some contributing factors may be 1) failure of the data to find a section to combine with in the digital map, or 2) sections occurring as multiple parts due to irregular state boundaries, shorelines, or to non-PLS land surveys. The first type of error results in a decrease in the expected number of claims in the digital map. The second results in an increase. Both sources of error may be present. A ratio of the grand totals of all claims of Table 1 to Table 2 should show the degree of fit of the digital map totals to the original database totals. A value equal to 1 indicates a $100 \%$ fit. A value less than 1 indicates data was lost. A value greater than 1 indicates multi-part sections may be in the digital PLS map. The table shows that the digital map contains 251,086 mining claims but the database contains 251,086 mining claims. A ratio of the two numbers, 1.000, indicates a complete fit.

Table 1. Mining claim totals by type and status in Wyoming (database linked to digital map)

\begin{tabular}{||l|c|c|c|c|r||}
\hline \hline & \multicolumn{5}{|c||}{ DIGITAL MAP DATABASE CLAIM TOTALS } \\
\hline \multicolumn{1}{||c|}{ Type of Claim } & LODE & PLACER & MILL & TUNNEL & ALL CLAIMS \\
\hline $\begin{array}{l}\text { Number of Open } \\
\text { Mining Claims }\end{array}$ & 11568 & 4181 & 918 & 0 & 16667 \\
\hline $\begin{array}{l}\text { Number of Closed } \\
\text { Mining Claims }\end{array}$ & 214291 & 16956 & 3158 & 4 & 234419 \\
\hline Grand Totals & 225859 & 21137 & 4076 & 4 & 251086 \\
\hline \hline
\end{tabular}

Table 2. Mining claim totals by type and status in Wyoming (wy_clms2.clms database)

\begin{tabular}{||l|c|c|c|c|r||}
\hline \hline & \multicolumn{5}{|c||}{ DENSITY DATABASE CLAIM TOTALS } \\
\hline \multicolumn{1}{|c|}{ Type of Claim } & LODE & PLACER & MILL & TUNNEL & ALL CLAIMS \\
\hline $\begin{array}{l}\text { Number of Open } \\
\text { Mining Claims }\end{array}$ & 11568 & 4181 & 918 & 0 & 16667 \\
\hline $\begin{array}{l}\text { Number of Closed } \\
\text { Mining Claims }\end{array}$ & 214291 & 16956 & 3158 & 4 & 234419 \\
\hline Grand Totals & 225859 & 21137 & 4076 & 4 & 251086 \\
\hline \hline
\end{tabular}

Another concern regarding accuracy involves the visual representation of the data to a viewer. The digital map does not accurately represent the aerial extent of the lands covered by a mining claim because the presence of one mining claim, about 20 acres for a lode claim, will 'color in' the entire section (640 acres) it occurs in. A section is typically 1 square mile. The visual representation of one claim is magnified by a factor of 32 times its actual size. The best digital map resolution available at this time is to the section. Any area calculations done with the digital map for mining claims will likely be unreliable. Specific information about a particular area should be acquired from the BLM State office.

Additionally, the positional accuracy of a mining claim is generalized to one section in the PLS even if it crosses into another section. Mining claims generally follow geologic features and usually do not conform to the PLS lines. The procedure used by Campbell (1996) chooses the first section listed for a mining claim in the MCRS as the section of position. This method insures that each claim is counted only once. The digital PLS map may have been derived from 1:100,000 source maps. It is considered accurate enough for geographic representations for the purposes of regional assessments at a scale of 1:100,000 or smaller. 


\section{MINING CLAIM DENSITY MAP CONTENTS}

Table 3 contains the structure and descriptions of specific fields within the digital map, wy_clms2. Table 4 contains the structure and descriptions of specific fields within the mining claim density database, wy_clms2.clms. The italicized field in bold type, $\boldsymbol{m t r s}$, is common to both the PLS and the database and is used by the relate file to link the database to the digital map.

Table 3. Field structure and descriptions of specific fields for the digital map

\begin{tabular}{||c|c|c|c|l|c|l||}
\hline \hline COLUMN & ITEM NAME & WIDTH & OUTPUT & TYPE & DEC & DESCRIPTION \\
\hline 1 & area & 8 & 18 & Floating & 5 & Internal Arc/Info polygon area \\
\hline 9 & perimeter & 8 & 18 & Floating & 5 & Internal Arc/Info polygon perimeter \\
\hline 17 & wy_clms2\# & 4 & 5 & Binary & - & Internal Arc/info polygon number \\
\hline 21 & wy_clms2-id & 4 & 5 & Binary & - & User-defined polygon number \\
\hline 25 & $\boldsymbol{m t r s}^{1}$ & 18 & 18 & Character & - & Meridian+Township+Range+Section \\
\hline
\end{tabular}

${ }^{1}$ For example, '06 30.0N 29.2E05' is Meridian 06, Township 30 North, Range 29 1/2 East, Section 5

Meridians include Sixth Principal (06) and Wind River (34).

Table 4. Field structure and descriptions for the mine claim density database

\begin{tabular}{||c|c|c|c|l|l|l||}
\hline \hline COLUMN & ITEM NAME & WIDTH & OUTPUT & TYPE & DEC & DESCRIPTION \\
\hline 17 & mtrs $^{1}$ & 18 & 18 & Character & - & Meridian+Township+Range+Section \\
\hline 35 & nolc $^{2}$ & 4 & 4 & Integer & - & Number of Open Lode Claims \\
\hline 39 & nopc & 4 & 4 & Integer & - & Number of Open Placer Claims \\
\hline 43 & nomc & 4 & 4 & Integer & - & Number of Open Mill site Claims \\
\hline 47 & notc & 4 & 4 & Integer & - & Number of Open Tunnel Claims \\
\hline 51 & toc & 4 & 4 & Integer & - & Total number of Open Claims \\
\hline 55 & nclc & 4 & 4 & Integer & - & Number of Closed Lode Claims \\
\hline 59 & ncpc & 4 & 4 & Integer & - & Number of Closed Placer Claims \\
\hline 63 & ncmc & 4 & 4 & Integer & - & Number of Closed Mill site Claims \\
\hline 67 & nctc & 4 & 4 & Integer & - & Number of Closed Tunnel Claims \\
\hline 71 & tcc & 4 & 4 & Integer & - & Total number of Closed Claims \\
\hline 75 & tc & 4 & 4 & Integer & - & Total number of Claims of all kinds \\
\hline \hline
\end{tabular}

${ }^{1}$ For example, '06 30.0N 29.2E05' is Meridian 06, Township 30 North, Range 29 1/2 East, Section 5

Meridians include Sixth Principal (06) and Wind River (34).

${ }^{2}$ in a section of the PLS

\section{REFERENCES}

Campbell, Harry W., 1996, Procedure from making a mining claim density map from BLM claim recordation digital data: U.S. Geological Survey Open-File Report 96-736, 13 p.

Hyndman, Paul C. and Harry W. Campbell, 1999, Digital databases containing mining claim density information for Arizona, California, Colorado, Idaho, Montana, Nebraska, New Mexico, Nevada, Oregon, South Dakota, Utah, Washington, and Wyoming created from the BLM Mining Claim Recordation System: 1996: U.S. Geological Survey Open-File Report 99-325, 23 p. 


\section{OBTAINING DIGITAL DATA}

The digital mining claim density map of Wyoming, wy_clms2, is provided with this report in Arc/Info EXPORT format as wy_clms2.e00. The mining claim density database, wy_clms.clms, and the relate file, wy_clms2.rel, are contained in the export file. A metadata file, wy_clms2.met, occurs separately. These files and this report are available from the USGS public access FTP site and the World Wide Web site on the Internet. Table 4 lists the files and their sizes.

Table 5. Files available with this Open-File Report

\begin{tabular}{|c|c|c||}
\hline \hline FILE NAME & FILE TYPE & SIZE IN KILOBYTES \\
\hline wy_ofr.pdf & PDF file & 261 \\
\hline wy_clms2.e00 & Arc/Info export & 17,473 \\
\hline wy_clms2.met & Metadata & 31 \\
\hline
\end{tabular}

\section{By Anonymous FTP}

Do the following steps to obtain the files for OF99-542 by anonymous ftp. Windows users may need to start FTP in the MSDOS window.

STEP (type the words between the quotes)

cd to your_local_directory

'ftp wrgis.wr.usgs.gov'

Name: 'anonymous'

Password: your email address

'cd pub/open-file'

'cd of 99-542'

'binary'

'get of99-542.exe'

'bye'
REASON

Go to a directory to receive the WinZip file - you may need to make a directory first Make ftp connection with the USGS computer, WRGIS

Use 'anonymous' as your user name Use your email address as a password (you@email address)

Go down to the pub/open-file directory Go down to the specific open file directory Type the word 'binary' to change the transfer type to binary mode

Copy the self-extracting file across the Internet to the receiving directory on your computer

Close the ftp connection

Extracting the files from the of99-542.exe self-extracting file is accomplished by typing the name of the file, 'of99-542', and pressing the 'Enter' key. The files will unload automatically.

\section{By the World Wide Web}

The files for this report can be obtained over the Internet at URL http://wrgis.wr.usgs.gov/open-file/. Do the following steps to obtain the files for OF99-542 by the World Wide Web:

STEP

Attach to the internet with your web browser

\section{REASON}

This connects you to the internet. 
Type 'http://wrgis.wr.usgs.gov/open-file/'

Find the report in the listing and click on of $99-542$

Follow the instructions for downloading the data and this report
Make sure the internet address looks like this to connect with the USGS computer, WRGIS

This opens a page with instructions and information for downloading the report

You should receive the report to your computer

\section{METADATA}

Following are 1) an Arc/Info description of the digital map, wy_clms2, 2) a description of the relate file, and 3) the formal metadata for the digital map and associated files.

\section{Description of SINGLE precision coverage wy_clms2}

\begin{tabular}{llllll} 
& \multicolumn{5}{c}{ FEATURE CLASSES } \\
Number of & Attribute & Spatial & \\
Feature Class & Subclass & Features & data (bytes) & Index? & Topology? \\
----------- & ---- & ----- \\
ARCS & ----- & -34400 & 28 & & Yes \\
POLYGONS & & 13047 & 42 & &
\end{tabular}

\section{SECONDARY FEATURES}

Tics

Arc Segments

Polygon Labels

Fuzzy $=56.095 \mathrm{~V}$

$\mathrm{Xmin}=-289685.625$

$Y \min =4844564.896$
272

35300

12484

TOLERANCES

COVERAGE BOUNDARY

$\mathrm{Xmax}=278203.138$

Ymax $=5291520.041$

STATUS

The coverage has not been Edited since the last BUILD or CLEAN

\section{COORDINATE SYSTEM DESCRIPTION}

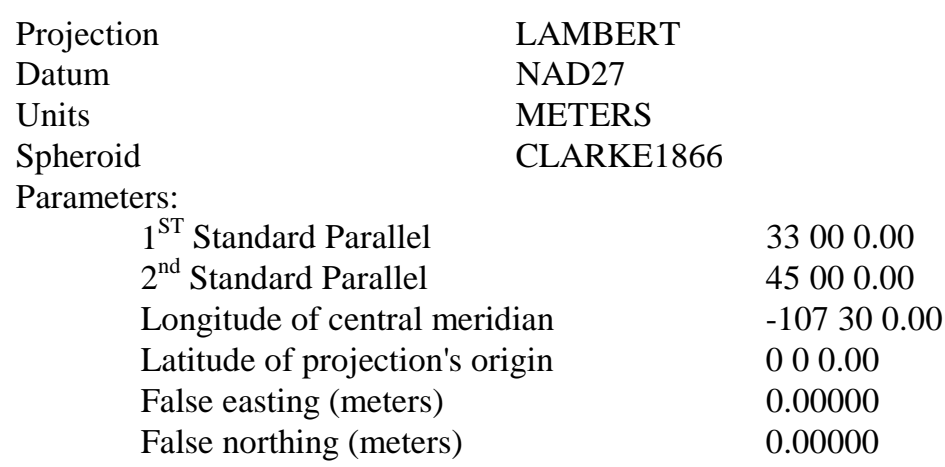




\section{Description of Arc/Info wy_clms2.rel relate structure}

$\begin{array}{ll}\text { Relation } & =\text { WY_CLMS2 } \\ \text { Table-Id } & =\text { wy_clms } 2 . \text { clms } \\ \text { Database } & =\text { info } \\ \text { Item } & =\text { MTRS } \\ \text { Column } & =\text { mtrs } \\ \text { Type } & =\text { ORDERED } \\ \text { Access } & =\text { RO }\end{array}$

\section{Formal metadata for the mine claim density map and associated files}

The following metadata describes the mining claim density map:

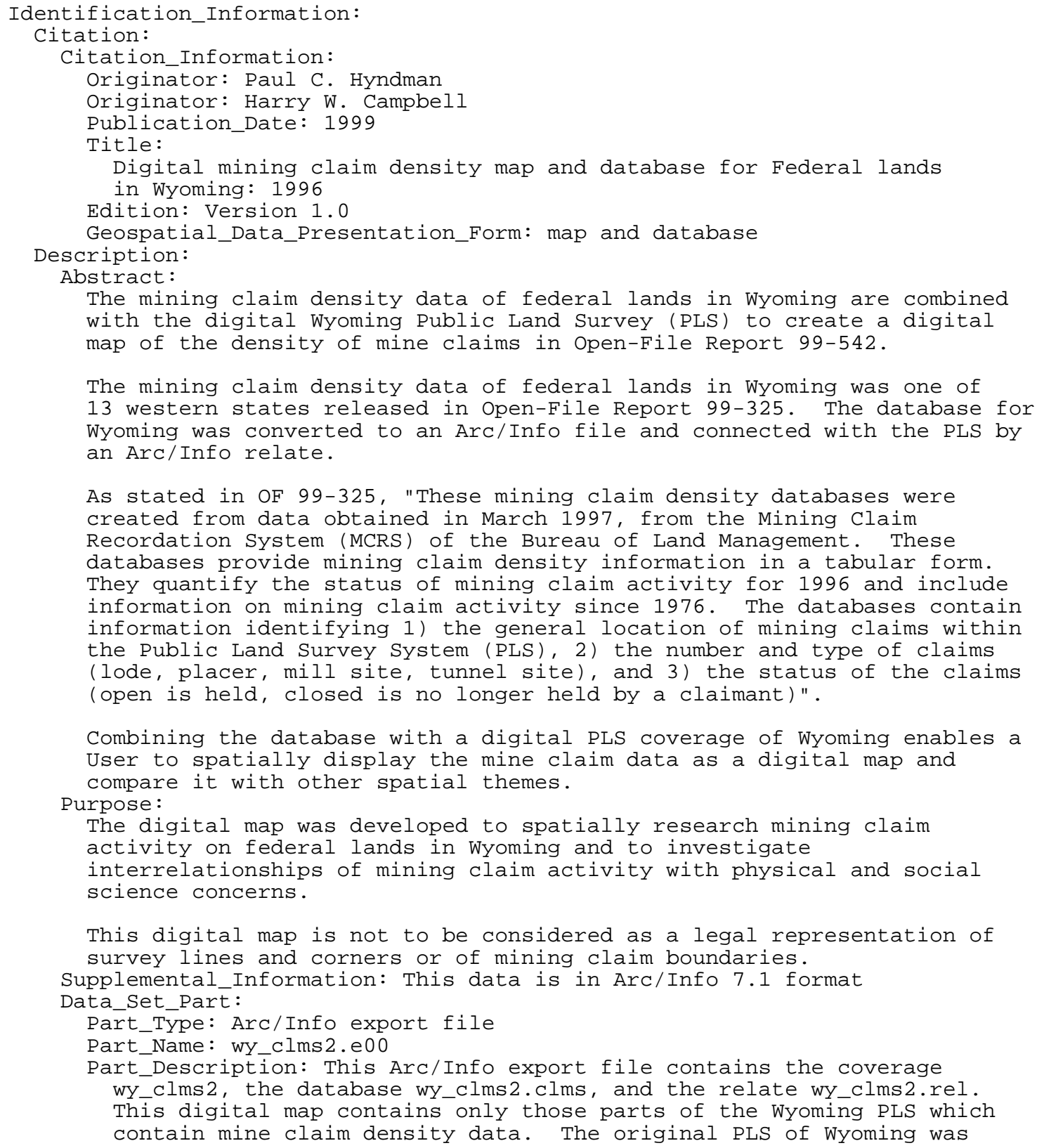


acquired from the U.S. Bureau of Mines when it was closed by Congress in 1996. The Bureau of Mines purchased the PLS of Wyoming from a private company. The data is proprietary and cannot be released in its complete form.

Data_Set_Part:

Part_Type: Arc/Info database

Part_Name: wy_clms2.clms

Part_Description: This database contains mine claim density information for federal lands in the state, from 1976 through 1996. It is one of several state databases from OF 99-325.

Data_Set_Part:

Part_Type: Arc/Info relate

Part_Name: wy_clms2.rel

Part_Description: This file contains the parameters needed to relate the database, wy_clms2.clms to the digital map database, wy_clms2.pat.

The structure of the relate is:

$\begin{array}{ll}\text { RELATION } & =\text { WY_CLMS2 } \\ \text { TABLE-ID } & =\text { wY_Clms2.clms } \\ \text { DATABASE } & =\text { info } \\ \text { ITEM } & =\text { MTRS } \\ \text { COLUMN } & =\text { mtrS } \\ \text { TYPE } & =\text { ORDERED } \\ \text { ACCESS } & =\text { RO }\end{array}$

Time Period of Content:

Time_Period_Information:

Range_of_Dates/Times:

Beginning_Date: 1976

Ending_Date: 1997

Currentness_Reference: Release date of data by the Bureau of Land Management in March, 1997

Status:

Progress: Complete

Maintenance_and_Update_Frequency: None planned

Spatial_Domain:

Bounding_Coordinates:

West_Bounding_Coordinate: -1110000

East_Bounding_Coordinate: -1040000

North_Bounding_Coordinate: 450000

South_Bounding_Coordinate: 410000

Keywords:

Theme:

Theme Keyword Thesaurus: None

Theme_Keyword: mining claim density

Theme_Keyword: lode

Theme_Keyword: placer

Theme_Keyword: mill site

Theme_keyword: tunnel site

Theme_Keyword: mine claim

Place:

Place_Keyword_Thesaurus: None

Place_Keyword: Wyoming

Access_Constraints: None

Use_Constraints:

Users should contact the BLM for current data. The U.S. Geological Survey

makes no warranties related to the accuracy of the data and users are

required to determine suitability of use for any particular purpose.

This digital map is not to be construed as a legal

representation of mining claim boundaries. The PLS data is assumed to be from 1:100,000 scale base maps. The map should not be used at scales larger than 1:100,000.

The user must obtain current information on mining claims from the Wyoming State Office of the Bureau of Land Management for the area of interest since the mining claim density data is not current. The information in the database does not provide the legal location or status of individual mining claims.

Any hardcopies utilizing this data set shall clearly indicate their source. If the user has modified the data in any way they are obligated to describe the types of modifications they have performed on the hardcopy map. User specifically agrees not to misrepresent 
this data set, nor to imply that changes they made were approved by the U.S. Geological Survey.

Point_of_Contact:

Contact_Information:

Contact_Person_Primary:

Contact_Person: Paul Hyndman

Contact_Organization: U.S. Geological Survey

Contact_Position: Geologist

Contact_Address:

Address_Type: mailing and physical address

Address: 904 W. Riverside Ave., Rm. 202

City: Spokane

State_or_Province: Washington

Postal_Code: 99201

Country: U.S.A.

Contact_Voice_Telephone: 509-368-3100 or 509-368-3118

Contact_Facsimile_Telephone: 509-368-3199

Contact_Electronic_Mail_Address: phyndmandusgs.gov

Contact_Instructions: General office phone is 509-368-3100

Data_Set_Credit:

Cheryl Laudenbach, Denver Service Center, BLM, provided the original

mining claim data from the Mining Claim Recordation Database. The data

was used to create the mining claim density databases in OF 99-325.

Native_Data_Set_Environment: Solaris 2.5.1, Sun Ultra 1, Arc/Info 7.1.2

Data_Quality_Information:

Attribute_Accuracy:

Attribute_Accuracy_Report:

OF $99-325$ reports that the attributes of the mining claim data from BLM

data, claims per section, do not represent the exact number of claims in each section. Some claims overlap into adjoining sections and/or

townships. In order to count each claim only once, it was necessary to

choose one section for each claim to be identified with. Therefore, the

first section listed in the BLM database for a particular claim was

chosen as the section the claim was counted in.

The accuracy was tested by summing each category of claim in the mining

claim database and comparing the sum to those from the original BLM

database. The sums for each category matched.

No attempt was made to determine the accuracy of BLM's database.

Completeness_Report:

None of the data from BLM was omitted. The data is considered complete

for the purpose of determining mining claim density in this state.

Logical_Consistency_Report:

The data set is a derived subset of the original BLM data. No

modifications to the BLM data were made.

Positional_Accuracy:

Horizontal_Positional_Accuracy:

Horizontal_Positional_Accuracy_Report:

A claim may be within a section or it may straddle two, three, or four

sections. In order to count each claim only once, it was

necessary to choose one section for each claim to be identified

with. Therefore, the first section listed in the BLM database

for a particular claim was chosen as the section the claim was

Lineage: counted in.

Source_Information:

Source_Citation:

Citation_Information:

Originator:

U.S. Geological Survey

Publication_Date: 1999

Title: Digital databases containing mining claim density information for Arizona, California, Colorado, Idaho, Montana, Nebraska, New Mexico, Nevada, Oregon, South Dakota, Utah, Washington, and Wyoming created from the BLM Mining Claim Recordation System: 1996 Edition: 1

Geospatial_Data_Presentation_Form: tabular database

Series_Information:

Series_Name: Open-File Report

Issue_Identification: OF 99-325 
Publication Information: Publication_Place: Denver, Colorado Publisher: U.S. Geological Survey

Other_Citation_Details:

Original data from the Bureau of Land Management Mine Claim Recordation Database (MCRD)

Online_Linkage: URL = http://wrgis.wr.usgs.gov/open-file/of99-325

Type_of_Source_Media: digital file

Source_Time_Period_of_content:

Time_Period_Information:

Range_of_Dates/Times:

Beginning_Date: 1976

Ending_Date: 199703

Source_Currentness_Reference:

The data were copied from BLM's MCRD database on March, 1997.

The data are cumulative from 1976, when the database was created. Source Citation Abbreviation: USGS OF99-325

Source_Contribution:

This database contributed the mine claim density information

needed to create a spatial mine claim density map.

Process_Step:

Process_Description:

The mine claim density database of Wyoming was released as part of

the U.S. Geological Open-File Report, OF 99-325. It was imported as an Arc/Info table, wy_clms2.clms, using the command, dbaseinfo. A relate, wy_clms2.rel, was made to connect the database to the PLS of Wyoming. This report can be found at URL:

http://wrgis.wr.usgs.gov/open-file/

Process_Date: 1997-1998

Data_Quality_Information:

Completeness_Report:

The digital PLS of Wyoming is assumed to be complete.

Logical Consistency Report:

The PLS in this report is a derived subset of the original PLS. Only those sections containing mine claim density data are included in this report.

Positional_Accuracy:

Horizontal_Positional_Accuracy:

Horizontal_Positional_Accuracy_Report:

No attempt was made to check the positional accuracy of the digital

Lineage:

PLS. The PLS is assumed to have come from 1:100,000 scale sources.

Source_Information:

Source_Citation:

Citation_Information:

Originator:

Uncertain. Digital PLS of Wyoming was obtained from the

U.S. Bureau of Mines at its closure in 1996. The data may have

been purchased from Geographic Information, Inc. in 1984. The

digital PLS is considered copyrighted and cannot be released in a form that would enable someone to reconstruct the PLS. Portions can be released in paper or digital form.

Publication_Date:

Title: none

Geospatial_Data_Presentation_Form: map

Type_of_Source_Media: digital file

Source_Time_Period_of_Content:

Time_Period_Information:

Single_Date/Time:

Calendar_Date: 1988

Source_Currentness_Reference:

The PLS may not be current with regard to section lines and corners. Source_Citation_Abbreviation: none

Source_Contribution:

The U.S. Bureau of Mines contributed the digital PLS of Wyoming. It

did not include metadata or other documentation.

Process_Step:

Process_Description:

The Wyoming PLS contained a field, mtrs, to which the mine claim

density database could be attached. The data was attached through the

use of a relate, wy_clms2.rel. An example of commands for using the 


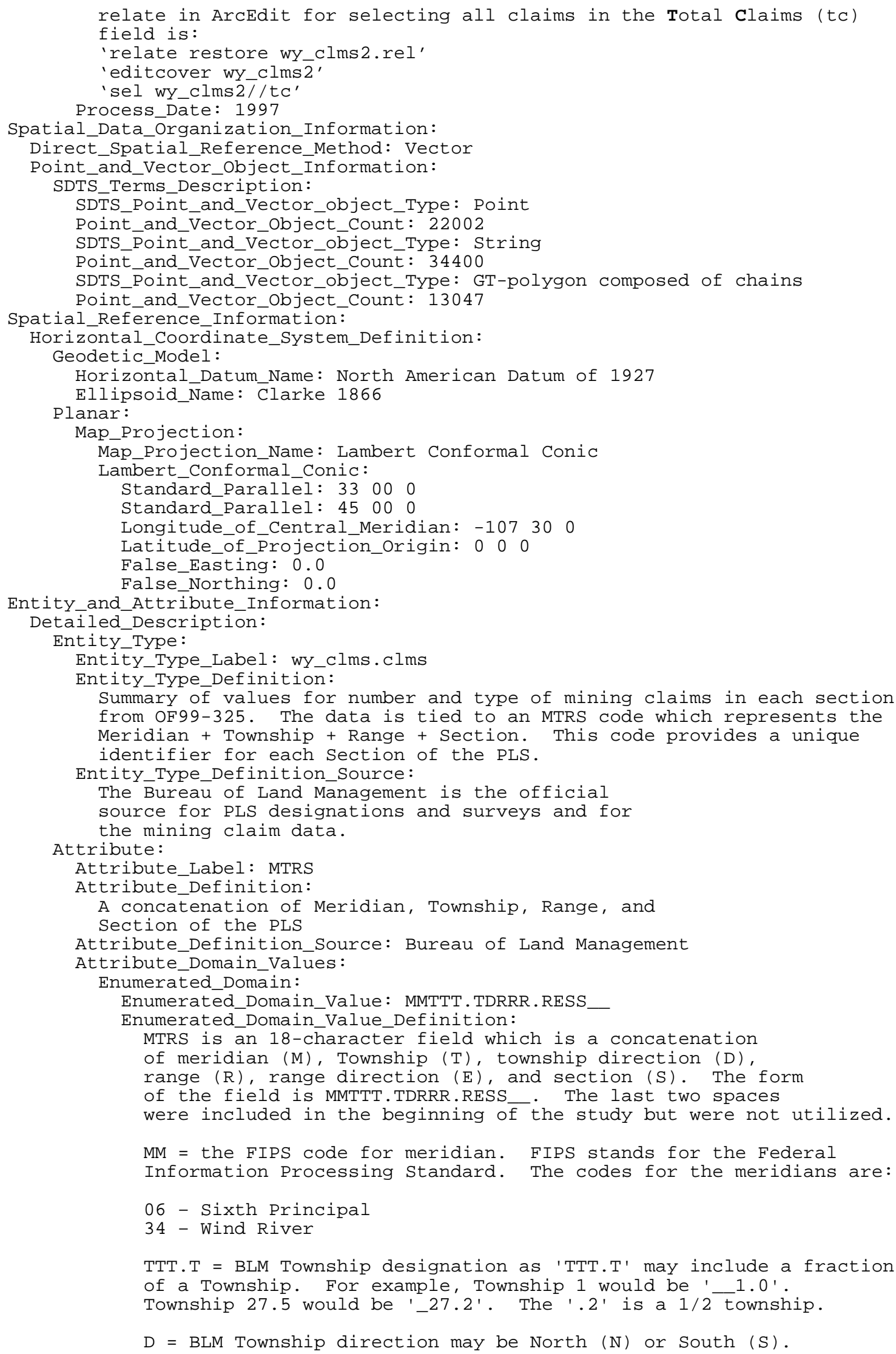




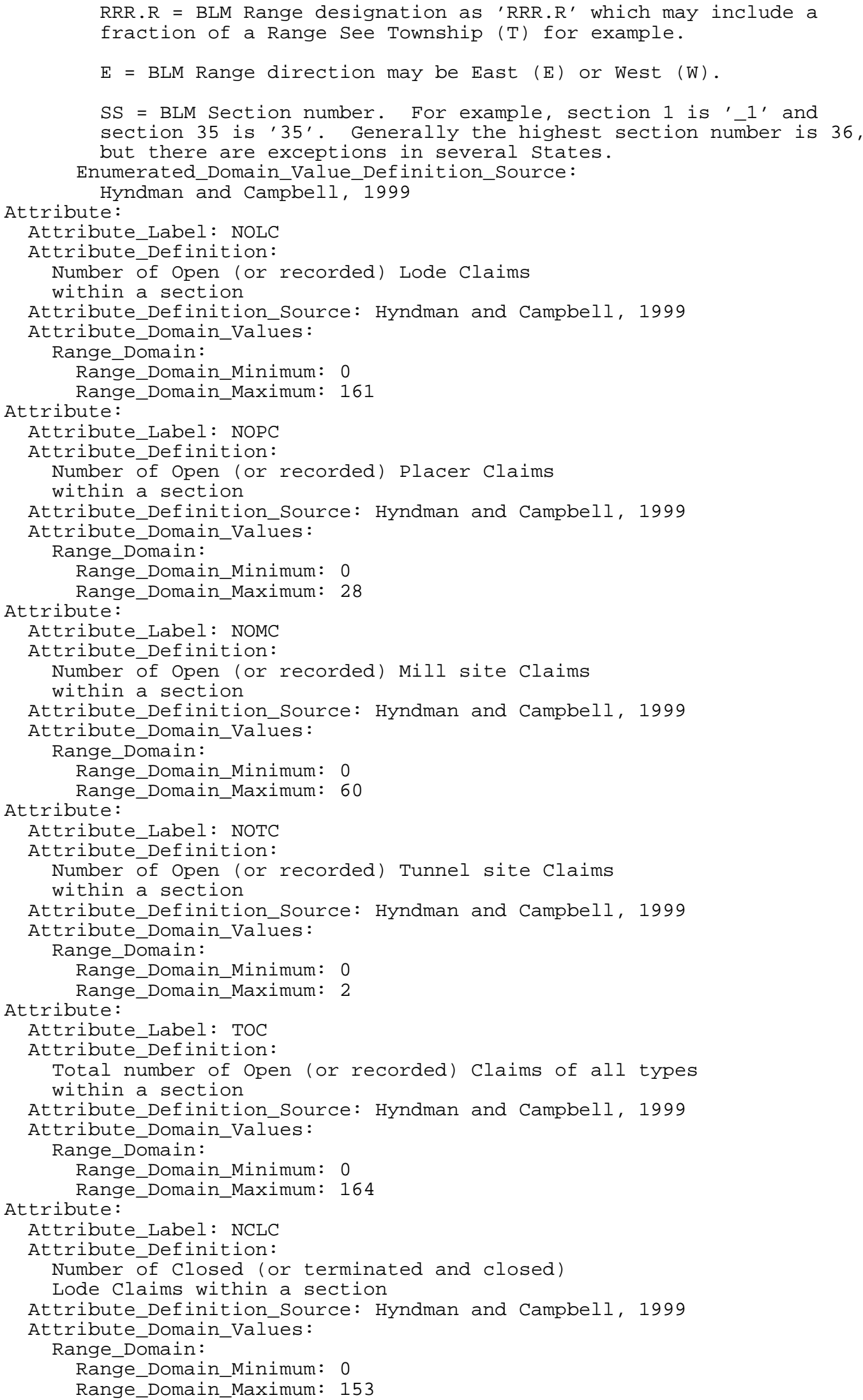




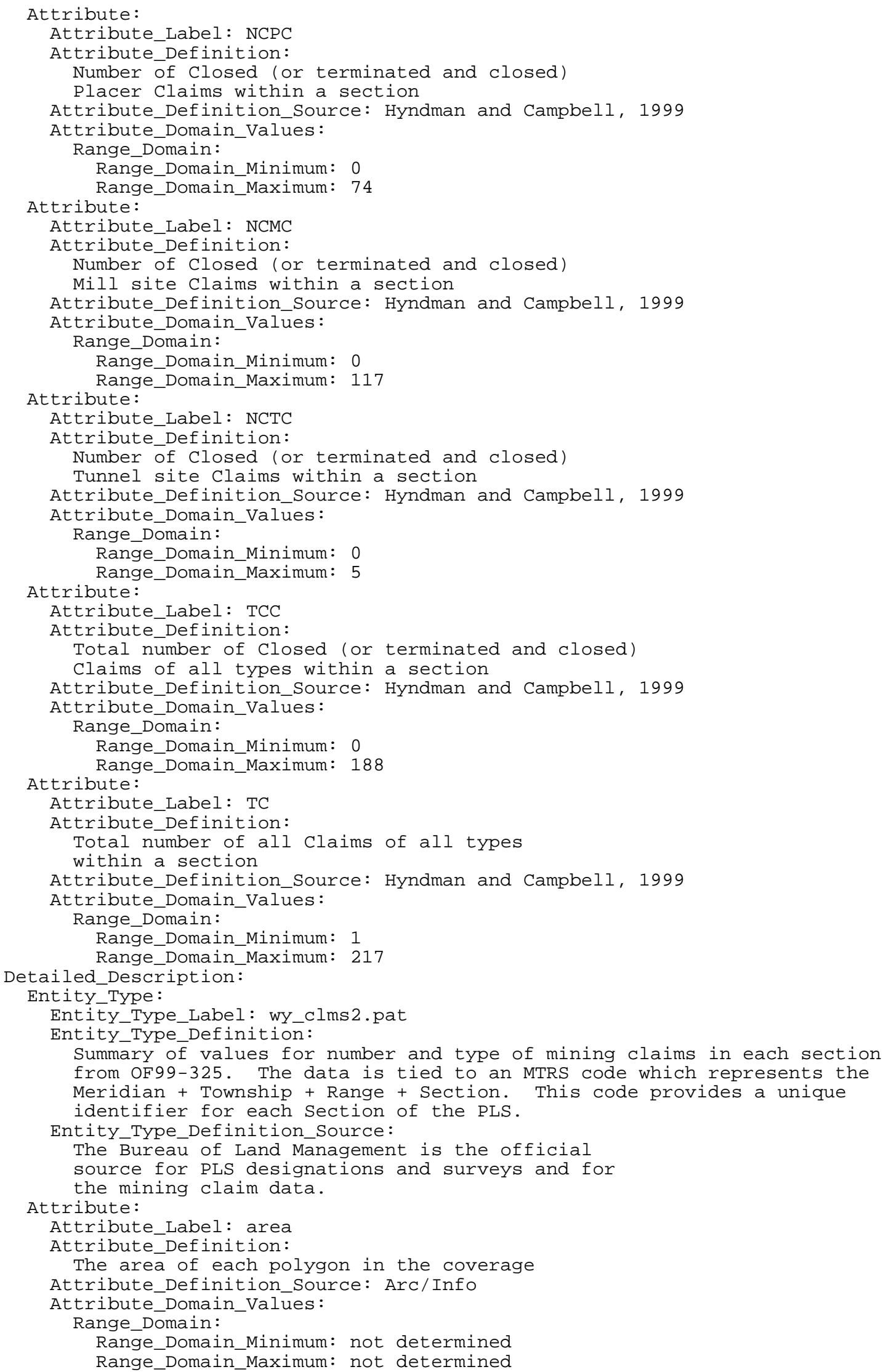




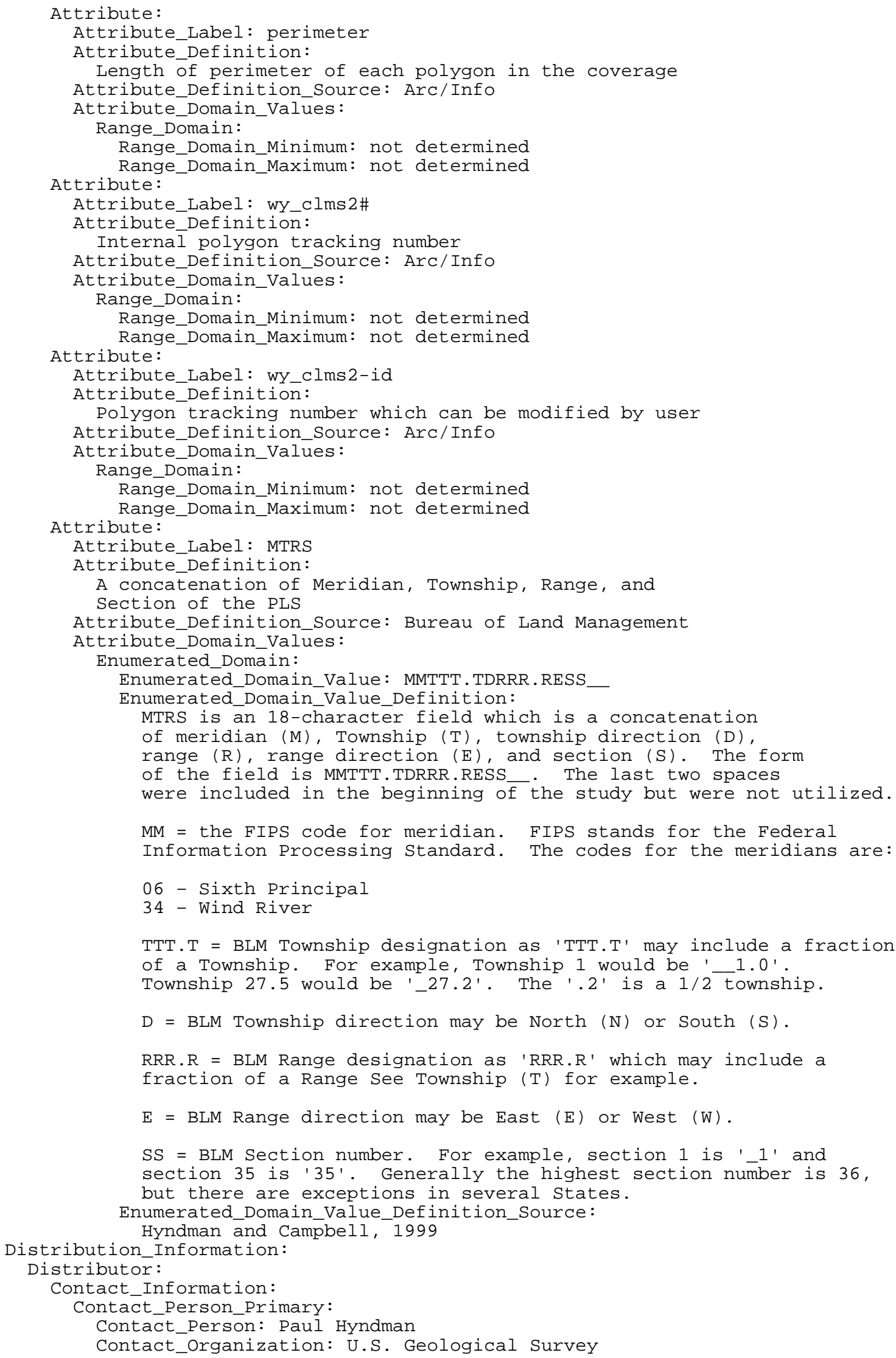


Contact_Position: Geologist

Contact_Address:

Address_Type: mailing and physical address

Address: W. 904 Riverside Avenue, Room 202

City: Spokane

State_or_Province: Washington

Postal_Code: 99201

Country: USA

Contact_Voice_Telephone: 509-368-3118

Contact_Facsimile_Telephone: 509-368-3199

Contact_Electronic_Mail_Address: phyndman@usgs.gov

Contact_Instructions: Main phone number is 509-368-3100

Resource_Description: Open-File Report 99-542

Distribution_Liability:

The U.S. Geological Survey (USGS) provides this data "as is."

The USGS makes no guarantee or warranty concerning the accuracy of information contained in the geographic data. The USGS further makes no warranties, either expressed or implied as to any other matter whatsoever, including, without limitation, the condition of the product, or its

fitness for any particular purpose. The burden for determining fitness for use lies entirely with the user. Although this data has been processed successfully on computers at the USGS, no warranty, expressed or implied, is made by the USGS regarding the use of this data on any other system, nor does the fact of distribution constitute or imply any such warranty.

In no event shall the USGS have any liability whatsoever for payment of any consequential, incidental, indirect, special, or tort damages of any kind, including, but not limited to, any loss of profits arising out of use of or reliance on the geographic data or arising out of the delivery, installation, operation, or support by the USGS.

Technical_Prerequisites: The user should have GIS software capable of reading Arc/Info export files

Distributor: Contact_Information:

Contact_Organization_Primary: Contact_Organization: U.S. Geological Survey Information Services Contact_Address:

Address_Type: mailing and physical address

Address : Open-File Reports

Box 2586

City: Denver

State_or_Province: CO

Postal_Code: 80225

Country: USA

Contact_Voice_Telephone: 1-303-202-4200

Contact_Facsimile_Telephone: 1-303-202-4693

Resource_Description: Open-File Report 99-542

Distribution_Liability:

The U.S. Geological Survey (USGS) provides this data "as is."

The USGS makes no guarantee or warranty concerning the accuracy of information contained in the geographic data. The USGS further makes no warranties, either expressed or implied as to any other matter whatsoever, including, without limitation, the condition of the product, or its fitness for any particular purpose. The burden for determining fitness for use lies entirely with the user. Although this data has been processed successfully on computers at the USGS, no warranty, expressed or implied, is made by the USGS regarding the use of this data on any other system, nor does the fact of distribution constitute or imply any such warranty.

In no event shall the USGS have any liability whatsoever for payment of any consequential, incidental, indirect, special, or tort damages of any kind, including, but not limited to, any loss of profits arising out of use of or reliance on the geographic data or arising out of the delivery, installation, operation, or support by the USGS.

Technical_Prerequisites: The user should have software GIS software capable of reading Arc/Info export files.

Distributor: Contact_Information: 
Contact_organization_Primary:

Contact_Organization: U.S.G.S. Earth Science Information Office

Contact_Address:

Address_Type: mailing and physical address

Address: 904 West Riverside Avenue, Rm 135

City: Spokane

State_or_Province: WA

Postal_Code: 99201

Country: USA

Contact_Voice_Telephone: 509-368-3130

Contact_Facsimile_Telephone: 509-353-2872

Contact_Electronic_Mail_Address: esnfic@mailmcan1.wr.usgs.gov

Hours_of_Service: 8:00 a.m. - 4:30 p.m. Pacific time zone

Resource_Description: Open-File Report 99-542

Distribution_Liability:

The U.S. Geological Survey (USGS) provides this data "as is."

The USGS makes no guarantee or warranty concerning the accuracy of

information contained in the geographic data. The USGS further makes no

warranties, either expressed or implied as to any other matter whatsoever, including, without limitation, the condition of the product, or its

fitness for any particular purpose. The burden for determining fitness

for use lies entirely with the user. Although this data has been

processed successfully on computers at the USGS, no warranty, expressed or implied, is made by the USGS regarding the use of this data on any other system, nor does the fact of distribution constitute or imply any such warranty.

In no event shall the USGS have any liability whatsoever for payment of any consequential, incidental, indirect, special, or tort damages of any kind, including, but not limited to, any loss of profits arising out of use of or reliance on the geographic data or arising out of the delivery, installation, operation, or support by the USGS.

Technical_Prerequisites: The user should have software GIS software capable of reading Arc/Info export files.

Metadata_Reference_Information:

Metadata_Date: 19990225

Metadata_Review_Date: 19990331

Metadata_Contact:

Contact_Information:

Contact_Person_Primary:

Contact_Person: Paul Hyndman

Contact_organization: U.S. Geological Survey

Contact_Position: Geologist

Contact_Address:

Address_Type: mailing and physical address

Address: W. 904 Riverside Avenue, Room 202

City: Spokane

State_or_Province: Washington

Postal_Code: 99201

Country: USA

Contact_Voice_Telephone: 509-368-3118

Contact_Facsimile_Telephone: 509-368-3199

Contact_Electronic_Mail_Address: phyndman@usgs.gov

Hours_of_Service: 8 am to $4: 30 \mathrm{pm}$

Contact_Instructions: Main phone is 509-368-3100

Metadata_Standard_Name: FGDC Content Standards for Digital Geospatial Metadata

Metadata_Standard_Version: FGDC-STD-001-1998

Metadata_Time_Convention: local time

Metadata_Access_Constraints: none

Metadata_Use_Constraints: none 